\title{
Chronic anterior uveitis in leprosy: an insidious cause of blindness
}

\author{
Cesar G Espiritu, Robert Gelber, H Bruce Ostler
}

\begin{abstract}
Chronic low grade anterior uveitis is the commonest cause of blindness in leprosy. It is usually asymptomatic until the late stages, and often patients seek help only after irreversible visual impairment has occurred. We present herewith several cases of this entity to emphasise the insidious nature of the disease, the extent of ocular damage it can cause, and the importance of early detection and treatment.
\end{abstract}

Leprosy causes ocular damage in four ways: (1) through paralysis of the trigeminal and facial nerve, resulting in lid abnormalities and corneal hypoaesthesia leading to corneal damage, infection, and opacification; (2) through direct bacterial invasion of the external eye, resulting in keratitis, scleritis, and iritis; (3) through iritis, which can occur during the reactional stages of the disease; and (4) through destruction of the autonomic nerve fibres supplying the eye, resulting in pinpoint pupil and a low grade iridocyclitis.

It is estimated that the incidence of iridocyclitis ranges from $5 \cdot 3 \%$ to $63 \%$, ${ }^{1-5}$ depending on the population studied and the completeness of examination. ${ }^{6}$ Acute anterior iridocyclitis is uncommon and occurs bilaterally. It develops during the reactional state erythema nodosum leprosum(ENL), is probably related to reduction of the T-suppressor cells, and is mediated through immune complex deposition. ${ }^{78}$ The acute iritis causes symptoms and signs so severe as to make the patient seek medical care.

The commonest form of anterior uveitis in leprosy is a chronic, low grade bilateral uveitis which produces minimal or no symptoms until late in the disease process. Cataracts, synechiae, pinpoint pupils, glaucoma, iris atrophy, and ciliary body damage occur insidiously, resulting in loss of vision. It has been postulated that this form of uveitis is neuroparalytic in origin. ${ }^{910}$

We present here five cases of chronic anterior uveitis in patients with lepromatous leprosy. Our cases emphasise the effects on the eye and the need for early detection, treatment, and frequent monitoring of the eye problem as part of the concurrent treatment of the systemic disease.

Foundation, University of San Francisco, San Francisco, California, USA

San Francisco Regional

Hansen's Disease

Program, San Francisco, California

C G Espiritu

R Gelber

H B Ostler

Correspondence to:

H Bruce Ostler, MD, 95

Kirkham Street, San

Francisco, CA 94122, USA.

Accepted for publication

6 September 1990 followed at the Hansen's Disease Centre, San Francisco. All cases were multibacillary and represented only part of the clinic's total cases of iridocyclitis. Besides the primary criteria of presenting with a chronic type of anterior uveitis, other bases for selection included: (1) adequate follow-up and monitoring, with the last visit within three months of the study; and (2) completeness of the medical as well as ocular records.

The ocular examination in each patient had included a visual acuity examination, slit-lamp examination, applanation tonometry, corneal anaesthesiometry, and Schirmer tests.

\section{Results}

All five cases illustrate the known characteristics of this commonest form of uveitis in Hansen's Disease. We present one patient in depth and the others in summary form through Table 1 .

\section{CASE REPORT}

A 72-year-old man with lepromatous leprosy (LL) for eight years was initially treated with dapsone (DDS) $50 \mathrm{mg}$ per day and rifampicin $600 \mathrm{mg}$ per day. Rifampicin was discontinued in 1987 but he continued to take DDS. In 1985 he developed erythema nodosum leprosum and was treated with thalidomide $300 \mathrm{mg}$ per day for eight months. His disease was subsequently relatively quiescent except for the ENL reaction.

In 1985 we saw the patient for routine ocular screening. He had no ocular complaints. Examination revealed no redness, and a visual acuity of 20/30 in both eyes. There were $1+$ cells and flare, fine keratic precipitates, and Koeppe nodules without evidence of posterior or anterior synechiae. The intraocular pressures were $13 \mathrm{mmHg}$ in each eye. The patient was treated with dexamethasone $0 \cdot 1 \%$ four times daily and phenylephrine $10 \%$ twice daily. Three months later the eyes were quiet, and we reduced the medication to twice daily.

When seen two months later the patient had no symptoms, and his visual acuity had not changed, but he was found to have $1+$ cells and flare in the left eye. There were no Koeppe nodules. Bilateral trichiasis and superior superficial keratitis secondary to Hansen's disease were also evident. The intraocular pressures were $8 \mathrm{mmHg}$ in each eye. We increased his dexamethasone to four times daily, phenylephrine to three times daily, and added cyclopentolate $1 \%$ twice daily. The patient improved, and after two months the iridocyclitis had cleared, and the dexamethasone and phenylephrine were continued once daily.

Six months later the patient had a complaint of mild redness of the left eye and volunteered that he had used the medications only sporadically. He was found to have a faint ciliary injection, and the anterior chamber of the left eye had $3+$ cells and $2+$ flare. There were medium white keratic 
Table 1 Profile of five patients with chronic anterior uveitis

\begin{tabular}{|c|c|c|c|c|c|c|c|c|c|c|}
\hline$I D$ & $\begin{array}{l}\text { Leprosy } \\
\text { classif. }\end{array}$ & $\begin{array}{l}\text { Disease } \\
\text { duration (yr) }\end{array}$ & Treatment & Activity & $\begin{array}{l}\text { Ocular } \\
\text { symptoms }\end{array}$ & $\begin{array}{l}\text { Iritis } \\
\text { findings }\end{array}$ & $\begin{array}{l}\text { Visual } \\
\text { acuity }\end{array}$ & IOP & $\begin{array}{l}\text { Iritis } \\
\text { treatment }\end{array}$ & $\begin{array}{l}\text { Response to } \\
\text { treatment }\end{array}$ \\
\hline $\begin{array}{l}51 \text { yr male } \\
\text { Filipino }\end{array}$ & LL & 19 & DDS & None & None & $\begin{array}{l}\text { OU: } 1+\text { cells-flare } \\
\text { fine KPs }\end{array}$ & OU: $20 / 30$ & OU: 13 & $\begin{array}{l}\text { Prednis, neos, } \\
\text { cyclo }\end{array}$ & Good control \\
\hline $\begin{array}{l}30 \text { yr male } \\
\text { Filipino }\end{array}$ & BT & 11 & $\begin{array}{l}\text { DDS, rifampicin, } \\
\text { prednis }\end{array}$ & $\begin{array}{c}\text {, None since } \\
1985\end{array}$ & Mild redness OS & OS: $1+$ cells/flare & $20 / 15$ & $\begin{array}{r}10 \\
4\end{array}$ & Neos, decadr & Good control \\
\hline $\begin{array}{l}29 \text { yr male } \\
\text { Filipino }\end{array}$ & BT & 7 & $\begin{array}{l}\text { Thalidomide, } \\
\text { DDS, } \\
\text { rifampicin }\end{array}$ & None & $\begin{array}{l}\text { Mild redness and } \\
\text { blurring OS }\end{array}$ & OU: $1+$ cells/flare & OU: $20 / 20$ & $\begin{array}{l}10 \\
11\end{array}$ & $\begin{array}{l}\text { Prednis, } \\
\text { mydriac, } \\
\text { neos }\end{array}$ & Good control \\
\hline $\begin{array}{l}73 \text { yr female } \\
\text { Laotian }\end{array}$ & BT & 8 & $\begin{array}{l}\text { DDS, } \\
\text { rifampicin, } \\
\text { prednis }\end{array}$ & $\begin{array}{l}\text { None since } \\
1983\end{array}$ & $\begin{array}{l}\text { Blurring OU, } \\
\text { redness, } \\
\text { photophobia }\end{array}$ & OU: $1+$ cells/flare & $\begin{array}{l}20 / 50 \\
20 / 70\end{array}$ & $\begin{array}{l}4 \\
8\end{array}$ & Neos, decadr & Good control \\
\hline
\end{tabular}

LL =lepromatous leprosy. BT = borderline tuberculoid. DDS=dapsone. Prednis=prednisolone acetate $1 \%$ (Pred Forte) ophthalmic solution. Neos=phenylephrine hydrochloride $10 \%$ (Neo-Synephrine) ophthalmic solution. Cyclo=cylopentolate hydrochloride $1 \%$ (Cyclogyl) ophthalmic solution. Mydriac=tropicamide $1 \%$ (Mydriacyl) ophthalmic solution. Decardr $=$ dexamethasone phosphate. $0 \cdot 1 \%$ (Decadron) phthalmic solution. $\mathrm{KP}=$ keratic precipitate. ID=identification.

precipitates and posterior synechiae at the 10 o'clock position. The intraocular pressure was 14 mmHg. We prescribed dexamethasone $0 \cdot 1 \%$ every hour, and phenylephrine $10 \%$ three times daily. The patient improved, and the medications were tapered to once daily.

During the following three years the patient had six more episodes of low grade iritis in the left eye. In each instance there were no ocular symptoms. The inflammation responded promptly and adequately to increase in the corticosteroid and phenylephrine, but recurred in spite of maintenance therapy. During the three-year period the intraocular pressures varied between 10 to $15 \mathrm{mmHg}$. Additional posterior synechiae formed, and about $15^{\circ}$ of the pupil are now bound down. He has also developed a posterior subcapsular cataract which has reduced his vision to $20 / 70$.

The other four cases are summarised in Table 1 .

\section{Discussion}

Ocular complications occur more frequently in leprosy than in any other systemic infection. They cause blindness in about $5 \%$ of patients. ${ }^{8}$ Blindness occurs in chronic iridocyclitis from development of a band keratopathy, pinpoint pupil, a non-reactive pupil, pigment deposits on the anterior lens capsule, posterior synechiae, secondary complicated cataract, cyclitic membranes, and secondary glaucoma or hypotony. ${ }^{1}$

In our five cases we encountered only posterior synechiae and complicated cataracts, which is in marked contrast to other reports of cases in which severe ocular changes were observed.

Two factors probably explain the difference in our results. (1) In our patients the diagnosis of Hansen's disease was made early and treatment was started early (none had evidence of systemic activity when we saw them). (2) The iridocyclitis was detected early and treatment started prior to development of sequelae (all patients with lepromatous leprosy in the Hansen's Disease Program, San Francisco, are screened by the clinic nurse with the aid of a slit-lamp, and any questionable cases are referred to the ophthalmologist, which allows for early diagnosis and treatment of patients with a chronic low grade iridocyclitis).

There are differing views on the genesis of chronic anterior uveitis in leprosy. Several investigators believe it is infective in origin, when bacilli present in the iris and ciliary body. ${ }^{5113}$ Others believe that there is a neuroparalytic cause. In theory leprosy bacilli lodge in the non-myelinated autonomic nerves of the iris as part of the generalised bacteraemia that occurs in the early stages of lepromatous leprosy. This causes a slow degeneration of the nerves leading to secondary muscle atrophy with release of toxins that brings about a chronic low grade inflammation. Evidence to support this view has been presented in the literature. ffytche ${ }^{9}$ and Garg $e t a l^{10}$ have demonstrated the absence of acid fast bacilli in the aqueous and iris in all specimens taken from cases of lepromatous leprosy with chronic low grade uveitis. The low grade non-specific inflammatory changes observed in their studies, as opposed to an active granulomatous process, suggest that this process is not a result of direct bacterial invasion.

Indirect evidence from previous work also supports the involvement of autonomic nerves of the iris. Pharmacologically Swift and Bauschard ${ }^{14}$ described the early autonomic denervation hypersensitivity present in lepromatous patients whose pupils abnormally dilated with Lepinephrine. A poor response to anticholinergic drugs such as atropine observed clinically can also be attributed to a derangement in adrenergic nerve fibres. Hussein $e t a l^{15}$ alluded to an autonomic (adrenergic) neuropathy of the anterior segment of the eye of patients with lepromatous leprosy by demonstrating significant postural changes in intraocular pressure (greater than $30 \%)$.

If the chronicity and low grade nature of the anterior uveitis arises from muscular atrophy secondary to destruction of iris sympathetic nerves, then the relative dependence of these cases on topical steroids and mydriatics commonly employed in their treatment is readily explained. All of our patients required a maintenance regimen to keep their iritis under control, and we observed that discontinuing topical medications resulted in an increase in the anterior chamber reaction. These patients require sustained therapy and monitoring for as long as this degenerative process persists.

\section{RECOMMENDATIONS}

The chronicity, insidious nature of this entity, and the importance of early detection and treatment of its activity and complications cannot be overemphasised. Similarly, early detection and eradication of lepromatous leprosy with the help of modern multidrug therapy may reduce the 
incidence of iridocyclitis and its seriously damaging effect on the eye.

Co-ordination and co-operation of the medical and paramedical personnel involved with the delivery of health care to leprosy patients must be established. Ideally, early screening for ocular complications, to detect asymptomatic disease, should be done with a slit-lamp by one who is knowledgeable in its use and of the eye findings present in leprosy. Regular, frequent (every one to six months) eye visits are advisable depending on the severity of the uveitis and its response to therapy. Visual acuity testing, intraocular pressure readings, and slit-lamp examination should be done during each follow-up. In addition, supervision of continuing steroid and mydriatic therapy at home is necessary to ensure proper, sustained management.

1 Lamba PA, Santoshkumar D, Arthanariswaran R. Ocular leprosy - a new perspective. Indian f Lepr 1983; 55: 490-5.
2 Spaide RT, Nattis R, Lipka A, D'Amico R. Ocular findings in leprosy in the United States. Am $\mathcal{F}$ Ophthalmol 1985; 100: 411-6

3 Ticho U, Ben Sira I. Ocular leprosy in Malawi. $\mathrm{Br} f$ Ophthalmol 1970; 54: 107-12.

4 Rohatgi J, Shorey P, Lamba PA, Sehgal VN. Uveal changes in leprosy. Indian f Lepr 1986; 58: 208-15.

5 Weerekoon L. Ocular leprosy in Ceylon. Br $\mathcal{F}$ Ophthalmol 1969; 53: 457-65.

6 Courtright PD. Defining the magnitude of ocular complications from leprosy: problems of methodology. Int $\mathcal{F}$ plications from leprosy: problems of me
Lepr Other Mycobact Dis 1988; 56: 566-73.

7 Mshana RN. Hypothesis: erythema nodosum leprosum is precipitated by an imbalance of T lymphocytes. Lepr Rev precipitated by

8 Murray PI, Kerr Muir MG, Rahi AHS. Immunopathogenesis of acute lepromatous uveitis: a case report. Lepr Rev 1986; 57: $163-8$.

9 ffytche TJ. Role of iris changes as a cause of blindness in lepromatous leprosy. Brf Ophthalmol 1981; 65: 231-9.

10 Garg SP, Kalra VK, Verma N. Aetiopathogenesis of lepromatous iritis. Indian 7 Ophthalmol 1983; 31: 869-71.

11 Suryawanshi N. Clinical manifestations of iridocyclitis in leprosy. Indian F Lepr 1985; 57: 549-55.

12 Choyce DP. Diagnosis and management of ocular leprosy. Brf Ophthalmol 1969; 53: 217-23.

13 Cameron AN. Leprosy and its ocular manifestations. Trans Ophthalmol Soc UK 1961; 81: 637-40.

14 Swift TR, Bauschard FB. Pupillary reactions in lepromatous leprosy. Indian $\mathcal{F}$ Lepr 1972; 40: 142-5.

15 Hussein N, Courtright P, Ostler HB, Hetherington J, Gelber $\mathrm{RH}$. Low intraocular pressure and postural changes in intraocular pressure in patients with Hansen's disease. $A m \mathcal{F}$ Ophthalmol 1989; 108: 80-3. 